\title{
PENERAPAN METODE LINEAR PROGRAMMING UNTUK ANALISIS PEMOTONGAN BESI TULANGAN PADA PROYEK BANGUNAN GEDUNG DI JAKARTA
}

\author{
Jennyfer Margaretta ${ }^{1}$, Onnyxiforus Gondokusumo ${ }^{2}$ \\ ${ }^{1}$ Mahasiswa Program Studi Teknik Sipil, Universitas Tarumanagara \\ E-mail: jennyfermargaretta@gmail.com \\ ${ }^{2}$ Dosen Program Studi Teknik Sipil, Universitas Tarumanagara \\ E-mail: onnyxiforusg@pps.untar.ac.id
}

\begin{abstract}
ABSTRAK
Material besi tulangan merupakan komponen yang penting dalam sebuah proyek konstruksi gedung bertingkat. Pada proyek di lapangan tidak dapat dihindari munculnya sisa material besi tulangan yang menyebabkan pengeluaran anggaran biaya yang sia-sia. Pemotongan besi tulangan yang tidak optimal di lapangan merupakan penyebab terjadinya waste besi yang cukup tinggi, sehingga diperlukan solusi untuk mengurangi waste besi. Metode Linear Programming merupakan salah satu solusi untuk mengurangi waste besi dan jumlah besi tulangan. Tujuan dilakukan penelitian ini untuk mengetahui pemotongan besi tulangan yang optimal dengan waste besi dan biaya yang kecil. Selain itu juga mengetahui perbedaan sisa pemotongan besi tulangan di lapangan dengan sisa pemotongan besi tulangan menggunakan Metode Linear Programming. Untuk menghasilkan nilai waste besi dan jumlah besi tulangan dari model Linear Programming diperlukan bantuan program LINDO. Penelitian ini dilakukan pada dua proyek konstruksi gedung bertingkat di Jakarta.Dalam penelitian ini terdapat dua cara yang digunakan dalam menghasilkan persentase penghematan, yaitu cara pertama, mengerjakan berdasarkan diameter pada pekerjaan masing-masing dan cara kedua, mengerjakan berdasarkan diameter yang digabungkan. Untukcara pertama didapatkan penghematan sebesar 3,6\% untuk proyek $X$ dan 3,9\% untuk proyek $Y$, sedangkan untuk cara kedua didapatkan penghematan sebesar4\% untuk proyek X dan 4,51\% untuk proyek $Y$. Berdasarkan hasil tersebut, maka disimpulkan bahwa cara pertama yang lebih layak untuk dilaksanakan di lapangan karena tidak membutuhkan waktu pengerjaan yang lama.
\end{abstract}

Kata kunci: wastebesi,Linear Programming, program LINDO, besi tulangan, Bar Bending Schedule

\section{PENDAHULUAN}

Material konstruksi merupakan komponen yang sangat penting dalam pelaksanaan proyek dan menentukan besarnya biaya suatu proyek. Pada pelaksanaan proyek di lapangan tidak dapat dihindari munculnya sisa material konstruksi. Pelaku konstruksi sering tidak menyadari bahwa sisa ini telah membuat biaya proyek menjadi tidak terkendali sehingga terjadi pembengkakan biaya/cost overrun (Kusuma, 2013).

Jika dilihat dari sisi penyebab terjadinya sisa material, perubahan-perubahan desain merupakan faktor yang paling sering menyebabkan terjadinya sisa atau limbah. Sedangkan jika dilihat dari pengaruh faktor penyebab terjadinya sisa material besi terhadap kegiatan konstruksi, maka pemotongan besi beton bertulang yang tidak optimal merupakan faktor yang paling mempengaruhi terjadinya sisa material besi (Kork, 2013).

Salah satu alternatif untuk mengoptimalkan pemotongan besi adalah dengan metode Linear Programming. Penulis membuat Bar Bending Schedule dengan menggunakan Microsoft Excel dan menyelesaikan persamaan linear dengan program LINDO, kemudian dilakukan perbandingan antara sebelum dan sesudah memakai metode Linear Programming.

Penelitian dilakukan pada dua proyek konstruksi gedung bertingkat di Jakarta.Fokus penelitian dititikberatkan pada upaya optimasi pemotongan besi tulangan di lapangan.Analisis dilakukan untuk memperoleh perbandingan wastebesi dan jumlah besi tulangan antara sebelum dan sesudah memakai metode Linear Programming. 
Ada beberapa tujuan yang ingin dicapai pada penelitian ini. Tujuan pertama adalah merumuskan hal-hal yang perlu diperhatikan dalam pembuatan model Linear Programming untuk memperoleh waste besi terkecil/jumlah besi yang sesuai kebutuhan. Tujuan kedua adalah menghitung besarnya penghematan dengan metode Linear Programming. Tujuan ketiga adalah mempelajari sejauh mana metode Linear Programming dapat digunakan untuk merencanakan pemotongan besi tulangan di proyek.

\section{METODE PENELITIAN}

Pada penelitian ini, Penulis mendatangi proyek dan melakukan survey serta pengumpulan data. Data yang dikumpulkan berupa data umum proyek, Bar Bending Schedule (BBS), Shop Drawingdan observasi. Setelah mendapatkan data yang diperlukan, langkah selanjutnya adalah memeriksa kelengkapan data, lalu melakukan rekapitulasi data Bar Bending Schedule (BBS).Barbending scheduleadalahdaftarpola pembengkokan besi tulanganyangmeliputidata diameter,bentuk,panjang danjumlahtulangan(ACI116R-00). Data-data ini kemudian disusun dalam bentuk tabel (Wahyu, 2014).

Langkah selanjutnya adalah membuat persamaan Linear Programming.Linear Programming adalah suatu alat yang digunakan untuk menyelesaikan masalah optimasi suatu model linear dengan keterbatasan- keterbatasan sumber daya yang tersedia. Terdapat dua macam fungsi yaitu fungsi tujuan dan fungsi kendala. Persamaan Linear Programmingdianalisis lebih lanjut dengan program LINDO.Output data yang dihasilkan adalah waste besitotal, jumlah tulangan besi pada masing-masing alternatif dan total batang besi yang diperlukan. Setelah itu dilakukan perbandingan pada wastebesi dan jumlah besi tulangan hasil di lapangan dengan perhitungan metode Linear Programming. Dari hasil analisis itu ditarik kesimpulan dan saran.

\section{HASIL DAN PEMBAHASAN}

\section{Hasil Analisis Lapangan}

Penelitian dilakukan pada dua proyek di Jakarta yaitu proyek X dan proyek Y. Berikut adalah hasil analisis di lapangan untuk proyek X. Dari panjang dan jumlah potongan yang didapat dari setiap pekerjaan di lapangan seperti pekerjaan pelat, balok, kolom dan shearwall kemudian dibuat Bar Bending Schedule (BBS) sesuai dengan diameter tulangan. Tabel 1 merupakan salah satu contoh pekerjaan pelat pada proyek X lantai 5.

Tabel 1. BBSLantai 5 untuk Pekerjaan Pelat Diameter 10

\begin{tabular}{|c|c|c|c|c|}
\hline \multirow{2}{*}{ As Pada Proyek X } & Panjang Potongan & Jumlah Potongan & Kebutuhan Besi (12m) & Waste Besi \\
\hline & $\mathrm{M}$ & batang & batang & $\mathrm{m} /$ batang \\
\hline \multicolumn{5}{|c|}{ ARAH X } \\
\hline \multicolumn{5}{|c|}{ ATAS } \\
\hline \multirow{3}{*}{ As $11-15 / \mathrm{A}-\mathrm{B}+\mathrm{C}-\mathrm{D}$} & 12 & 167 & 167 & 0 \\
\hline & 12 & 334 & 334 & 0 \\
\hline & 3,6 & 167 & 56 & 1,2 \\
\hline \multirow{2}{*}{ As $11-13 / \mathrm{B}-\mathrm{C}$} & 12 & 64 & 64 & 0 \\
\hline & 7,1 & 64 & 64 & 4,9 \\
\hline \multirow{2}{*}{ As $14-15 / \mathrm{B}-\mathrm{C}$} & 12 & 64 & 64 & 0 \\
\hline & 1,76 & 64 & 11 & 1,44 \\
\hline \multicolumn{5}{|c|}{ BAWAH } \\
\hline \multirow{3}{*}{ As $11-15 / \mathrm{A}-\mathrm{B}+\mathrm{C}-\mathrm{D}$} & 12 & 120 & 120 & 0 \\
\hline & 12 & 240 & 240 & 0 \\
\hline & 3,6 & 120 & 40 & 1,2 \\
\hline \multirow{2}{*}{ As $11-13 / \mathrm{B}-\mathrm{C}$} & 12 & 46 & 46 & 0 \\
\hline & 7,1 & 46 & 46 & 4,9 \\
\hline
\end{tabular}




\begin{tabular}{|c|c|c|c|c|}
\hline \multirow{2}{*}{ As $14-15 / \mathrm{B}-\mathrm{C}$} & 12 & 46 & 46 & 0 \\
\hline & 1,76 & 46 & 8 & 1,44 \\
\hline \multicolumn{5}{|c|}{ ARAH Y (ATAS+BAWAH) } \\
\hline \multirow{3}{*}{ As A-D/11-13+14-15 } & 12 & 288 & 288 & 0 \\
\hline & 12 & 288 & 288 & 0 \\
\hline & 5,8 & 288 & 144 & 0,4 \\
\hline As A-B, C-D/13-14 & 8,04 & 160 & 160 & 3,96 \\
\hline
\end{tabular}

Kebutuhan batang didapat dari jumlah potongan dibagi jumlah besi. Jumlah besi didapat dengan membagikan panjang besi $(12 \mathrm{~m})$ dengan panjang potongan. Sedangkan waste besi adalah sisa pemotongan dari besi utuh $(12 \mathrm{~m})$ dikurangi jumlah besi hasil pemotongan dikali panjang potongan.Berikut ini adalah contoh pada penulangan pelat lantai arah $\mathrm{X}$ atas As 11-15/A-B+C-D baris 3 tabel 1.

Jumlah besi $=12 / 3,6=3,3$ buah $=3$ buah

Kebutuhan batang $=167 / 3=56$ batang

Waste besi 3,6 = 12-3x3,6=1,2 $\mathrm{m}$

\section{Rekapitulasi BBS}

Bar Bending Schedule (BBS) yang didapat di lapangan perlu direkapitulasi untuk mempermudah perhitungan penelitian. Hasil rekapitulasi BBS untuk pekerjaan pelat dapat dilihat pada tabel 2. Tabel 2 merupakan contoh analisis lebih lanjut dari pekerjaan pelat proyek X lantai 5 (tabel 1).

Tabel 2. Rekapitulasi Bar Bending Schedule Pekerjaan Pelat Lantai Diameter 10

\begin{tabular}{|r|r|r|r|r|r|}
\hline Panjang & Jumlah Potongan & Panjang Total & Kebutuhan Besi $(12 \mathrm{~m})$ & Waste Besi & Waste Besi \\
\hline $\mathrm{m}$ & \multicolumn{1}{|c|}{ batang } & $\mathrm{m}$ & batang & m per batang & \multicolumn{1}{c|}{$\mathrm{m}$} \\
\hline 1,76 & 110 & 193,6 & 19 & 1,44 & 27,36 \\
\hline 3,6 & 287 & $1.033,2$ & 96 & 1,2 & 115,2 \\
\hline 5,8 & 288 & $1.670,4$ & 144 & 0,4 & 57,6 \\
\hline 7,1 & 110 & 781 & 110 & 4,9 & 539 \\
\hline 8,04 & 160 & $1.286,4$ & 160 & 3,96 & 633,6 \\
\hline 12 & 1.657 & 19.884 & 1.657 & 0 & 0 \\
\hline & & $\Sigma$ & 2.186 & $\sum$ & $1.372,76$ \\
\hline
\end{tabular}

\section{Linear Programming}

Untuk memodelkan permasalahan Linear Programmingdari tabel 2, maka langkah-langkah yang harus dilakukan adalah menentukan:

a. Variabel Keputusan

Variabel keputusan dalam analisis pemotongan besi pada penelitian ini adalah jumlah besi tulangan pada diameter tulangan tertentu dengan pola/alternatif pemotongan besi yang berbeda-beda seperti pada tabel 3. X1-x12 adalah.... dimna contohnya dapat dilihat

Tabel 3. Alternatif Pemotongan Besi Tulangan Pelat Lantai Diameter 10

\begin{tabular}{|c|c|c|c|c|c|c|c|c|c|}
\hline Jumlah Potongan & 110 & 287 & 288 & 110 & 160 & 1657 & \multirow{3}{*}{ sisa } \\
\cline { 1 - 7 } & \multicolumn{7}{|c|}{ Panjang (m) } & \\
\cline { 2 - 7 } & 1,76 & 3,6 & 5,8 & 7,1 & 8,04 & 12 & \\
\hline X1 & & & & & & 1 & 0 \\
\hline X2 & & 1 & & & 1 & & 0,36 \\
\hline X3 & 2 & & & & 1 & & 0,44 \\
\hline X4 & & 1 & & 1 & & & 1,3 \\
\hline
\end{tabular}




\begin{tabular}{|c|c|c|c|c|c|c|c|}
\hline X5 & 2 & & & 1 & & & 1,38 \\
\hline X6 & & & 2 & & & & 0,4 \\
\hline X7 & 1 & 1 & 1 & & & & 0,84 \\
\hline X8 & 3 & & 1 & & & & 0,92 \\
\hline X10 & & 3 & & & & & 1,2 \\
\hline X11 & 4 & 1 & & & & & 1,36 \\
\hline X12 & 6 & & & & & & 1,44 \\
\hline
\end{tabular}

Terdapat 12 alternatif untuk panjang potongan pada pelat lantai untuk diameter tulangan 10 $\mathrm{mm}$. Untuk memperjelas maksud dari tabel 3, maka dapat dilihat pada contoh alternatif X3. $\mathrm{X} 3$ adalah jumlah besi tulangan ukuran $12 \mathrm{~m}$ untuk alternatif pemotongan 2 batang besi ukuran $1,76 \mathrm{~m}$ dan 1 batang besi ukuran $8,04 \mathrm{~m}$. Sisa besi pada alternatif X3 adalah 12 $(2 \times 1,76)-8,04=0,44 \mathrm{~m}$. Untuk lebih jelas dapat dilihat pada gambar 1.

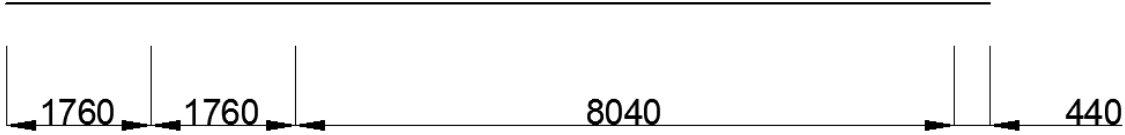

Gambar 1. Alternatif X3

b. Fungsi Tujuan

Fungsi tujuan dari penelitian ini adalah mengetahui nilai minimum total wastebesi di lapangan berdasarkan masing-masing pekerjaan dan diameter.

MIN $\quad Z=$ $0 \mathrm{X} 1+0,36 \mathrm{X} 2+0,44 \mathrm{X} 3+1,3 \mathrm{X} 4+1,38 \times 5+0,4 \mathrm{X} 6+0,84 \mathrm{X} 7+0,92 \mathrm{X} 8+1,2 \mathrm{X} 9+1,28 \mathrm{X} 10+1,36 \mathrm{X} 11+$ $1,44 \mathrm{X} 12$

Pada alternatif X1 tidak terdapat sisa besi sehingga 0 dikalikan X1 jadi $0 X 1$, Pada alternatif $\mathrm{X} 2$ terdapat sisa besi $0,36 \mathrm{~m}$ sehingga 0,36 dikalikan X2 menjadi 0,36X2 dan seterusnya.

c. Fungsi Kendala

Batasan-batasan dari penelitian ini terdapat pada jumlah potongan dari masing-masing panjang potongan yang dianalisis.

$\mathrm{X} 1>=1657$

$\mathrm{X} 2+\mathrm{X} 3>=160$

$\mathrm{X} 4+\mathrm{X} 5>=110$

$2 \mathrm{X} 6+\mathrm{X} 7+\mathrm{X} 8>=288$

$\mathrm{X} 2+\mathrm{X} 4+\mathrm{X} 7+3 \mathrm{X} 9+2 \mathrm{X} 10+\mathrm{X} 11>=287$

$2 \mathrm{X} 3+2 \mathrm{X} 5+\mathrm{X} 7+3 \mathrm{X} 8+2 \mathrm{X} 10+4 \mathrm{X} 11+6 \mathrm{X} 12>=110$

Dari tabel 3, jumlah potongan 1675 batang untuk alternatif X1 (lihat per kolom), sedangkan jumlah potongan 160 batang untuk alternatif X2 dan X3.

\section{Program LINDO}

Input data:

MIN

$0 \mathrm{X} 1+0,36 \mathrm{X} 2+0,44 \mathrm{X} 3+1,3 \mathrm{X} 4+1,38 \times 5+0,4 \mathrm{X} 6+0,84 \mathrm{X} 7+0,92 \times 8+1,2 \mathrm{X} 9+1,28 \mathrm{X} 10+1,36 \mathrm{X} 11+1,44$

$\mathrm{X} 12$

ST

$\mathrm{X} 1>=1657$

$\mathrm{X} 2+\mathrm{X} 3>=160$ 
$\mathrm{X} 4+\mathrm{X} 5>=110$

$2 \mathrm{X} 6+\mathrm{X} 7+\mathrm{X} 8>=288$

$\mathrm{X} 2+\mathrm{X} 4+\mathrm{X} 7+3 \mathrm{X} 9+2 \mathrm{X} 10+\mathrm{X} 11>=287$

$2 \mathrm{X} 3+2 \mathrm{X} 5+\mathrm{X} 7+3 \mathrm{X} 8+2 \mathrm{X} 10+4 \mathrm{X} 11+6 \mathrm{X} 12>=110$

END

Output data:

Waste besitotal $=288,52 \mathrm{~m}$

Jumlah tulangan besi ukuran $12 \mathrm{~m}$ untuk alternatif pemotongan:

$\mathrm{X} 1=1.657$ batang

$\mathrm{X} 2=232$ batang

$\mathrm{X} 4=55$ batang

$\mathrm{X} 5=55$ batang

X6 $=144$ batang

Jumlah batang besi $=1657+232+55+55+144=2.143$ batang

Analisis Hasil Perhitungan Metode Linear Programming (LP)

Hal yang sama juga dilakukan untuk pekerjaan balok, kolom dan shear wall, sehingga didapatkan hasil pada tabel 4 .

Tabel 4. Hasil Analisis Lapangan dan Linear ProgrammingProyek X

\begin{tabular}{|c|r|r|r|r|r|}
\hline \multirow{2}{*}{ Pekerjaan } & \multirow{2}{*}{ Diameter } & \multicolumn{2}{c|}{ Kebutuhan Besi (batang) } & \multicolumn{2}{c|}{ Waste Besi (m) } \\
\cline { 2 - 6 } & & Lapangan & \multicolumn{1}{c|}{ LP } & Lapangan & \multicolumn{1}{c|}{ LP } \\
\hline Pelat & 10 & 2.186 & 2.143 & $1.372,76$ & 288,52 \\
\hline \multirow{3}{*}{ Balok } & 10 & 563 & 661 & 140,18 & 8,25 \\
\cline { 2 - 6 } & 19 & 181 & 178 & 108,04 & 58,44 \\
\cline { 2 - 6 } & 22 & 297 & 297 & 106,44 & 106,44 \\
\hline \multirow{3}{*}{ Kolom } & 10 & 90 & 84 & 103,68 & 31,68 \\
\cline { 2 - 6 } & 13 & 846 & 1.248 & $1.009,44$ & 207,36 \\
\hline \multirow{4}{*}{\begin{tabular}{c} 
Shear \\
\cline { 2 - 6 }
\end{tabular}} & 32 & 120 & 120 & 144 & 144 \\
\cline { 2 - 6 } & 10 & 30 & 29 & 7,65 & 0,58 \\
\cline { 2 - 6 } & 13 & 27 & 42 & 36,6 & 7,28 \\
\cline { 2 - 6 } & 19 & 14 & 14 & 628,16 & 232,16 \\
\cline { 2 - 6 } & 22 & 46 & 46 & 0 & 0 \\
\hline
\end{tabular}

Pada tabel 4, waste besi hasil perhitungan dengan integer programming menjadi kecil namun ada beberapa pekerjaan pada kebutuhan besinya menjadi lebih besar. Untuk membatasi jumlah kebutuhan besi agar tepat seperti yang dibutuhkan di lapangan atau tidak terlalu jauh dari jumlah kebutuhan besi yang dibutuhkan di lapangan maka dilakukan pergantian simbol " $>=$ " menjadi "=" pada fungsi kendala (constraints). Hasil analisisnya dapat dilihat pada tabel 5 dan 6.

Tabel 5. Hasil Analisis Antara " $>=$ " dengan "="

\begin{tabular}{|l|r|r|r|r|r|}
\hline \multirow{2}{*}{ Pekerjaan } & \multirow{2}{*}{ Diameter } & \multicolumn{2}{|c|}{ Kebutuhan Besi (batang) } & \multicolumn{2}{c|}{ Waste Besi (m) } \\
\cline { 3 - 6 } & & Min Waste $(>=)$ & Min Besi (=) & Min Waste $(>=)$ & Min Besi (=) \\
\hline Pelat & 10 & 2.143 & 2.095 & 288,52 & 291,4 \\
\hline \multirow{3}{*}{ Balok } & 10 & 661 & 555 & 8,25 & 36,72 \\
\cline { 2 - 6 } & 19 & 178 & 178 & 58,44 & 58,44 \\
\hline \multirow{3}{*}{ Kolom } & 22 & 297 & 297 & 106,44 & 106,44 \\
\cline { 2 - 6 } & 10 & 84 & 84 & 31,68 & 31,68 \\
\cline { 2 - 6 } & 13 & 1.248 & 765 & 207,36 & 253,88 \\
\cline { 2 - 6 } & 32 & 120 & 120 & 144 & 144 \\
\hline
\end{tabular}




\begin{tabular}{|l|r|r|r|r|r|} 
& 10 & 29 & 28 & 0,58 & 3,36 \\
\cline { 2 - 6 } & 13 & 42 & 25 & 7,28 & 13,1 \\
\cline { 2 - 6 } & 16 & 188 & 188 & 232,16 & 232,16 \\
\cline { 2 - 6 } & 19 & 14 & 14 & 0 & 0 \\
\cline { 2 - 6 } & 22 & 46 & 46 & 0 & 0 \\
\cline { 2 - 6 } & 25 & 150 & 150 & 675 & 675 \\
\hline
\end{tabular}

Tabel 6. Hasil Analisis Dalam Satuan Kg Proyek X

\begin{tabular}{|c|c|c|c|c|c|c|c|}
\hline \multirow[t]{2}{*}{ Pekerjaan } & \multirow[t]{2}{*}{ Dia } & \multicolumn{3}{|c|}{ Kebutuhan Besi (kg) } & \multicolumn{3}{|c|}{ Waste Besi (kg) } \\
\hline & & Lap & Min Waste (>=) & Min Besi (=) & Lap & Min Waste (>=) & Min Besi (=) \\
\hline Pelat & 10 & $16.176,4$ & $15.858,2$ & $15.503,0$ & 846,5 & 177,9 & 179,7 \\
\hline \multirow{3}{*}{ Balok } & 10 & $4.166,2$ & $4.891,4$ & $4.107,0$ & 86,4 & 5,1 & 22,6 \\
\hline & 19 & $4.843,6$ & $4.763,3$ & $4.763,3$ & 240,9 & 130,3 & 130,3 \\
\hline & 22 & $10.620,7$ & $10.620,7$ & $10.620,7$ & 317,2 & 317,2 & 317,2 \\
\hline \multirow{3}{*}{ Kolom } & 10 & 666,0 & 621,6 & 621,6 & 63,9 & 19,5 & 19,5 \\
\hline & 13 & $10.558,1$ & $15.575,0$ & $9.547,2$ & $1.049,8$ & 215,7 & 264,0 \\
\hline & 32 & $9.086,4$ & $9.086,4$ & $9.086,4$ & 908,6 & 908,6 & 908,6 \\
\hline \multirow{6}{*}{ Shear wall } & 10 & 222,0 & 214,6 & 207,2 & 4,7 & 0,4 & 2,1 \\
\hline & 13 & 337,0 & 524,2 & 312,0 & 38,1 & 7,6 & 13,6 \\
\hline & 16 & $4.174,7$ & $3.551,3$ & $3.551,3$ & 988,8 & 365,5 & 365,5 \\
\hline & 19 & 374,6 & 374,6 & 374,6 & 0,0 & 0,0 & 0,0 \\
\hline & 22 & $1.645,0$ & $1.645,0$ & $1.645,0$ & 0,0 & 0,0 & 0,0 \\
\hline & 25 & $6.930,0$ & $6.930,0$ & $6.930,0$ & $2.598,8$ & $2.598,8$ & $2.598,8$ \\
\hline \multicolumn{2}{|c|}{ Jumlah } & $69.800,6$ & $74.656,3$ & $67.269,3$ & $7.143,9$ & $4.746,5$ & $4.822,0$ \\
\hline
\end{tabular}

Tabel 7. Hasil Analisis Perbandingan Minimum Besi Terhadap Minimum WasteProyek X

\begin{tabular}{|c|c|c|c|c|c|c|c|}
\hline \multirow{3}{*}{$\frac{\text { Pekerjaan }}{\text { Pelat }}$} & \multirow[b]{2}{*}{ Diameter } & \multirow{3}{*}{$\begin{array}{l}\text { Min Waste } \\
\mathrm{Kg} \\
15.858,20\end{array}$} & \multicolumn{5}{|c|}{ Selisih Antara Min Waste dengan Min Besi } \\
\hline & & & Batang & \multicolumn{2}{|c|}{$\mathrm{Kg}$} & \multicolumn{2}{|c|}{ Persentase (\%) } \\
\hline & 10 & & 48 & 355,2 & 355,2 & 2,24 & 2,2 \\
\hline \multirow{3}{*}{ Balok } & 10 & \multirow{3}{*}{$20.275,40$} & 106 & 784,4 & \multirow{3}{*}{784,4} & 16,04 & \multirow{3}{*}{3,9} \\
\hline & 19 & & 0 & 0 & & 0 & \\
\hline & 22 & & 0 & 0 & & 0 & \\
\hline \multirow{3}{*}{ Kolom } & 10 & \multirow{3}{*}{$25.283,00$} & 0 & 0 & \multirow{3}{*}{$6.027,80$} & 0 & \multirow{3}{*}{23,8} \\
\hline & 13 & & 483 & $6.027,80$ & & 38,7 & \\
\hline & 32 & & 0 & 0 & & 0 & \\
\hline \multirow{6}{*}{$\begin{array}{c}\text { Shear } \\
\text { wall }\end{array}$} & 10 & \multirow{6}{*}{$13.239,70$} & 1 & 7,4 & \multirow{6}{*}{219,6} & 3,45 & \multirow{6}{*}{1,7} \\
\hline & 13 & & 17 & 212,2 & & 40,48 & \\
\hline & 16 & & 0 & 0 & & 0 & \\
\hline & 19 & & 0 & 0 & & 0 & \\
\hline & 22 & & 0 & 0 & & 0 & \\
\hline & 25 & & 0 & 0 & & 0 & \\
\hline & Jumlah & $74.656,30$ & 655 & $7.387,00$ & 7.387 & 9,89 & 9,9 \\
\hline
\end{tabular}

Berikut adalah contoh perhitungan untuk pekerjaan balok pada tabel 7:

Min Waste $($ lihat tabel 6) $=\mathrm{D} 10+\mathrm{D} 19+\mathrm{D} 22=4.891,4+4.763,3+10.620,7=20.275,4 \mathrm{~kg}$

Batang Diameter 10 (lihat tabel 5) = min waste - min besi $=661-555=106$ batang

Kg Diameter 10 (lihat tabel 6) $=$ min waste - min besi $=4.891,4-4.107=784,4 \mathrm{~kg}$

Total kg diameter 10 (lihat tabel 6 dan 7) = D10+D19+D22=784,4+0+0=784,4 kg

Persentase Diameter 10 (lihat tabel 6) $=\mathrm{Kg} / \mathrm{min}$ wastex $100 \%=784,4 / 4.891,4 \times 100 \%=16,04 \%$

Total persentase pekerjaan balok $(\operatorname{tabel} 6$ dan 7$)=784.4 / 20.275,4 \times 100 \%=3,87 \%$ 
Tabel 8. Hasil Analisis Penghematan Minimum Besi Terhadap Lapangan pada Masing-Masing Diameter Pekerjaan Proyek X

\begin{tabular}{|c|c|c|c|c|c|}
\hline \multirow[t]{2}{*}{ Pekerjaan } & \multirow[t]{2}{*}{ Diameter } & \multicolumn{4}{|c|}{ Penghematan Min Besi Terhadap Lapangan } \\
\hline & & Batang & $\mathrm{Kg}$ & Persentase $(\%)$ & Rupiah (Rp) \\
\hline Pelat & 10 & 91 & 673,4 & 4,2 & 4.713 .800 \\
\hline \multirow{3}{*}{ Balok } & 10 & 8 & 59,2 & 1,4 & 414.400 \\
\hline & 19 & 3 & 80,3 & 1,7 & 561.960 \\
\hline & 22 & 0 & 0,0 & 0,0 & 0 \\
\hline \multirow{3}{*}{ Kolom } & 10 & 6 & 44,4 & 6,7 & 310.800 \\
\hline & 13 & 81 & $1.010,9$ & 9,6 & 7.076 .160 \\
\hline & 32 & 0 & 0,0 & 0,0 & 0 \\
\hline \multirow{6}{*}{ Shear wall } & 10 & 2 & 14,8 & 6,7 & 103.600 \\
\hline & 13 & 2 & 25,0 & 7,4 & 174.720 \\
\hline & 16 & 33 & 623,4 & 14,9 & 4.363 .590 \\
\hline & 19 & 0 & 0,0 & 0,0 & 0 \\
\hline & 22 & 0 & 0,0 & 0,0 & 0 \\
\hline & 25 & 0 & 0,0 & 0,0 & 0 \\
\hline \multicolumn{2}{|c|}{ Jumlah } & & $2.531,3$ & 3,6 & 17.719 .030 \\
\hline
\end{tabular}

Berikut adalah contoh perhitungan untuk hasil analisis pekerjaan pelat pada tabel 8: Batang (lihat tabel 4 dan 5)= lapangan-min besi=2.186-2.095=91 batang

$\mathrm{Kg}$ (lihat tabel 5)= lapangan-min besi $=16.176,4-15.858,2=673,4 \mathrm{~kg}$

Persentase $=\mathrm{kg}$ penghematan $/ \mathrm{kg}$ lapangan $\times 100 \%=673,4 / 16.176,4 \times 100 \%=4,16 \%$

Rupiah $(1 \mathrm{~kg}=\mathrm{Rp} 7.000,-)=\mathrm{kg}$ penghematan $\mathrm{x}$ biaya per $\mathrm{kg}=673,4 \times \mathrm{Rp} 7.000,--\mathrm{Rp} 4.713 .800,-$

Tabel 9. Hasil Analisis Penghematan Minimum Besi Terhadap Lapangan pada Masing-Masing Pekerjaan Proyek X

\begin{tabular}{|l|r|r|r|r|r|}
\hline \multirow{2}{*}{ Pekerjaan } & \multirow{2}{*}{ Lapangan $(\mathrm{Kg})$} & \multirow{2}{*}{ Min Besi $(\mathrm{Kg})$} & \multicolumn{3}{|c|}{ Penghematan Min Besi Terhadap Lapangan } \\
\cline { 4 - 6 } & & & \multicolumn{1}{|c|}{ Kg } & \multicolumn{1}{c|}{ Rp } \\
\hline Pelat & $16.176,4$ & $15.503,0$ & 673,4 & 4,2 & 4.713 .800 \\
\hline Balok & $19.630,5$ & $19.491,0$ & 139,5 & 0,7 & 976.360 \\
\hline Kolom & $20.310,5$ & $19.255,2$ & $1.055,3$ & 5,2 & 7.386 .960 \\
\hline Shear wall & $13.683,3$ & $13.020,1$ & 663,1 & 4,8 & 4.641 .910 \\
\hline Jumlah & $69.800,6$ & $67.269,3$ & $2.531,3$ & 3,6 & 17.719 .030 \\
\hline
\end{tabular}

Berikut adalah contoh perhitungan dibawah ini untuk pekerjaan balok pada tabel 9: Lapangan (lihat tabel 6) $=$ D10+D19+D22 $=4.166,2+4.843,6+10.620,7=19.630,5 \mathrm{~kg}$ Minimum besi (lihat tabel 6) $=$ D10+D19+D22 $=4.107+4.763,3+10.620,7=19.491 \mathrm{~kg}$ Penghematan $=$ lapangan - minimum besi $=19.630,5-19.491=139,5 \mathrm{~kg}$ Persentase $=$ Penghematan $/$ Lapangan $\times 100 \%=139,5 / 19.630,5 \times 100=0,71 \%$ Rupiah $(1 \mathrm{~kg}=\mathrm{Rp} 7000,-)=$ Penghematan $\mathrm{x}$ biaya per kg=139,5 x Rp7.000,-= Rp 976.360,-

Penghematan jika menggunakan metode Linear Programming dapat mencapai Rp17.719.030,dengan persentase 3,6 \% untuk lantai 5 pada Tower Office proyek X. Solusi lain yang dapat dilakukan yaitu dengan menggabungkan tulangan dengan diameter yang sama. Diameter tulangan yang dapat digabungkan adalah diameter $10 \mathrm{~mm}, 13 \mathrm{~mm}, 19 \mathrm{~mm}$, dan $22 \mathrm{~mm}$. Sehingga disusun menjadi sebuah tabel yang lebih singkat yang dapat dilihat pada tabel 10 . 
Tabel 10. Susunan Hasil Analisis Berdasarkan Diameter Besi Tulangan Proyek X

\begin{tabular}{|r|r|r|r|r|}
\hline \multirow{2}{*}{ Diameter } & \multicolumn{2}{|c|}{ Kebutuhan Besi (batang) } & \multicolumn{2}{c|}{ Waste Besi (m) } \\
\cline { 2 - 5 } & Lapangan & Minimum Besi & Lapangan & \multicolumn{1}{c|}{ Minimum Besi } \\
\hline 10 & 2.869 & 2.762 & $1.624,27$ & 363,16 \\
\hline 13 & 873 & 790 & $1.046,04$ & 266,98 \\
\hline 16 & 221 & 188 & 628,16 & 232,16 \\
\hline 19 & 195 & 192 & 108,04 & 58,44 \\
\hline 22 & 343 & 343 & 106,44 & 106,44 \\
\hline 25 & 150 & 150 & 675 & 675 \\
\hline 32 & 120 & 120 & 144 & 144 \\
\hline
\end{tabular}

Untuk diameter $10 \mathrm{~mm}, 13 \mathrm{~mm}, 19 \mathrm{~mm}$, dan $22 \mathrm{~mm}$ dilakukan analisis ulang dengan penambahan tipe-tipe panjang dan jumlah potongan dari tipe-tipe panjang tersebut dengan metode yang sama seperti sebelumnya. Hasil dari analisis dapat dilihat pada tabel 11.

Tabel 11. Hasil Analisis Ulang untuk Diameter yang Digabungkan Proyek X

\begin{tabular}{|r|r|r|r|r|}
\hline \multirow{2}{*}{ Diameter } & \multicolumn{2}{|c|}{ Kebutuhan Besi (batang) } & \multicolumn{2}{c|}{ Waste Besi (m) } \\
\cline { 2 - 5 } & \multicolumn{1}{|c|}{ Lapangan } & \multicolumn{1}{c|}{ Min Besi } & Lapangan & \multicolumn{1}{c|}{ Min Besi } \\
\hline 10 & 2.869 & 2.736 & $1.624,27$ & 65,89 \\
\hline 13 & 873 & 787 & $1.046,04$ & 247,06 \\
\hline 16 & 221 & 188 & 628,16 & 232,16 \\
\hline 19 & 195 & 192 & 108,04 & 58,44 \\
\hline 22 & 343 & 343 & 106,44 & 106,44 \\
\hline 25 & 150 & 150 & 675 & 675 \\
\hline 32 & 120 & 120 & 144 & 144 \\
\hline
\end{tabular}

Dengan menggabungkan pemotongan tulangan berdasarkan diameternya, dapat menurunkan atau memperkecil wastebesi dan jumlah tulangan. Penghematan dengan menggabungkan diameter pada semua pekerjaan pada lantai 5 proyek X dapat dilihat pada tabel 12.

Tabel 12.Hasil Analisis Penghematan Minimum Besi Terhadap Lapangan pada Masing-Masing Diameter Proyek X

\begin{tabular}{|c|r|r|r|r|r|}
\hline \multirow{2}{*}{ Diameter } & \multirow{2}{*}{ Lapangan $(\mathrm{Kg})$} & \multirow{2}{*}{ Min Besi $(\mathrm{Kg})$} & \multicolumn{3}{|c|}{ Penghematan Min Besi Terhadap Lapangan } \\
\cline { 4 - 6 } & & & \multicolumn{1}{|c|}{ Kg } & \multicolumn{1}{c|}{ Rp } \\
\hline 10 & $21.230,6$ & $20.246,4$ & 984,2 & 4,6 & 6.889 .400 \\
\hline 13 & $10.895,0$ & $9.821,8$ & $1.073,3$ & 9,9 & 7.512 .960 \\
\hline 16 & $4.174,7$ & $3.551,3$ & 623,4 & 14,9 & 4.363 .590 \\
\hline 19 & $5.218,2$ & $5.137,9$ & 80,3 & 1,5 & 561.960 \\
\hline 22 & $12.265,7$ & $12.265,7$ & 0,0 & 0 & 0 \\
\hline 25 & $6.930,0$ & $6.930,0$ & 0,0 & 0 & 0 \\
\hline 32 & $9.086,4$ & $9.086,4$ & 0,0 & 0 & 0 \\
\hline Jumlah & $69.800,6$ & $67.039,5$ & $2.761,1$ & 4 & 19.327 .910 \\
\hline
\end{tabular}

Cara perhitungan untuk tabel 12 sama dengan tabel 9. Penghematan jika menggabungkan diamater dari semua pekerjaan di lantai 5 dapat mencapai $\mathrm{Rp} 19.327 .910$,- dengan persentase 4\%. Selisih antara sebelum dan sesudah digabungkan yaitu Rp 19.327.910 - Rp 17.719.030= Rp $1.608 .880,-$.

\section{Rangkuman Hasil Analisis Perhitungan}

Berikut adalah hasil analisis proyek X dan proyek Y. Perhitungan analisis dengan metode linear programming untuk proyek Y sama dengan cara perhitungan pada proyek X.

a. Variasi Panjang Potongan dengan Variabel Keputusan 
Pada awal analisis perhitungan, dalam pembuatan model Linear Programming terlebih dahulu harus dibuat alternatif-alternatif pemotongan yang merupakan variabel keputusan dalam model Linear Programming.

Tabel 13. Rangkuman Jumlah Variasi Panjang Potongan dengan Variabel Keputusan yang Dihasilkan Pada Proyek X dan Proyek Y untuk Pekerjaan Masing-masing

\begin{tabular}{|c|c|c|c|c|}
\hline \multirow{2}{*}{ Proyek } & \multirow{2}{*}{ Pekerjaan } & \multirow{2}{*}{ Diameter } & \multicolumn{2}{|c|}{ Jumlah } \\
\hline & & & Panjang Potongan & Variabel Keputusan \\
\hline \multirow{13}{*}{$X$} & Pelat & 10 & 6 & 12 \\
\hline & \multirow{3}{*}{ Balok } & 10 & 10 & 105 \\
\hline & & 19 & 9 & 17 \\
\hline & & 22 & 7 & 13 \\
\hline & \multirow{3}{*}{ Kolom } & 10 & 2 & 4 \\
\hline & & 13 & 3 & 11 \\
\hline & & 32 & 1 & 1 \\
\hline & \multirow{6}{*}{$\begin{array}{l}\text { Shear } \\
\text { wall }\end{array}$} & 10 & 2 & 27 \\
\hline & & 13 & 3 & 16 \\
\hline & & 16 & 5 & 12 \\
\hline & & 19 & 1 & 1 \\
\hline & & 22 & 1 & 1 \\
\hline & & 25 & 1 & 1 \\
\hline \multirow{10}{*}{$\mathrm{Y}$} & \multirow{5}{*}{ Kolom } & 16 & 5 & 56 \\
\hline & & 19 & 6 & 123 \\
\hline & & 25 & 2 & 2 \\
\hline & & 29 & 1 & 1 \\
\hline & & 32 & 1 & 1 \\
\hline & \multirow{5}{*}{ Core wall } & 10 & 11 & 300 \\
\hline & & 13 & 4 & 8 \\
\hline & & 16 & 9 & 224 \\
\hline & & 19 & 5 & 108 \\
\hline & & 22 & 9 & 81 \\
\hline
\end{tabular}

Tabel 14. Rangkuman Jumlah Variasi Panjang Potongan dengan Variabel Keputusan yang Dihasilkan Pada Proyek X dan Proyek Y untuk Diameter yang Digabung

\begin{tabular}{|c|c|r|r|}
\hline \multirow{2}{*}{ Proyek } & \multirow{2}{*}{ Diameter } & \multicolumn{2}{|c|}{ Jumlah } \\
\cline { 3 - 4 } & & Panjang Potongan & Variabel Keputusan \\
\hline \multirow{3}{*}{$\mathrm{X}$} & 10 & 17 & 300 \\
\cline { 2 - 4 } & 13 & 10 & 129 \\
\cline { 2 - 4 } & 19 & 8 & 22 \\
\cline { 2 - 4 } & 22 & 14 & 18 \\
\hline \multirow{2}{*}{$\mathrm{Y}$} & 16 & 6 & 300 \\
\cline { 2 - 4 } & 19 & & 123 \\
\hline
\end{tabular}

b. Perbandingan Analisis Lapangan, Minimum Besi dan Minimum Waste

Hasil perbandingan analisis lapangan, min besi dan min waste dapat dilihat pada tabel 15 .

Tabel 15. Rangkuman Analisis Kebutuhan Tulangan dan Waste Besi dalam Satuan Kg untuk Proyek X dan Proyek Y

\begin{tabular}{|l|c|r|r|r|r|r|}
\hline \multirow{2}{*}{ Proyek } & \multicolumn{3}{|c|}{ Kebutuhan Besi (kg) } & \multicolumn{3}{c|}{ Waste Besi (kg) } \\
\cline { 2 - 7 } & \multicolumn{1}{|c|}{ Lap } & Min Waste (>=) & Min Besi (=) & Lap & Min Waste (>=) & \multicolumn{1}{c|}{ Min Besi (=) } \\
\hline $\mathrm{X}$ & $69.800,6$ & $74.656,3$ & $67.269,3$ & $7.143,9$ & $4.746,5$ & $4.822,00$ \\
\hline $\mathrm{Y}$ & $132.624,5$ & $151.497,1$ & $127.454,6$ & $7.534,8$ & $2.258,8$ & $2.785,20$ \\
\hline
\end{tabular}




\section{c. Penghematan}

Rangkuman hasil analisis untuk penghematan minimun besi terhadap lapangan berdasarkan pekerjaan dengan diameter masing-masing dan diameter yang digabung untuk proyek $\mathrm{X}$ pada lantai 5 dan proyek Y pada lantai 22 dapat dilihat pada tabel 16.

Tabel 16. Rangkuman Hasil Analisis Penghematan Minimum Besi Terhadap Lapangan Berdasarkan Pekerjaan dan Diameter Proyek X dan Proyek Y

\begin{tabular}{|l|r|l|r|l|}
\hline \multirow{2}{*}{ Keterangan } & \multicolumn{2}{|c|}{ Proyek X } & \multicolumn{2}{c|}{ Proyek Y } \\
\cline { 2 - 5 } & \multicolumn{1}{|c|}{$\%$} & Biaya (Rp) & \multicolumn{1}{l|}{$\%$} & Biaya (Rp) \\
\hline Pekerjaan & 3,6 & 17.719 .030 & 3,9 & 36.189 .090 \\
\hline Diameter & 4 & 19.327 .910 & 4,51 & 38.183 .530 \\
\hline
\end{tabular}

\section{KESIMPULAN DAN SARAN}

\section{Kesimpulan}

Berdasarkan hasil dan analisis dari penelitian ini, dapat ditarik kesimpulan sebagai berikut:

a. Dalam membuat model Linear Programming, ada 3 hal yang harus diperhatikan, yaitu variabel keputusan, fungsi tujuan dan fungsi kendala. Pada persamaan fungsi kendala dapat digunakan tanda " $>=$ " atau "=".

- Jika menggunakan tanda ">=", maka dapat menghasilkan kebutuhkan besi yang lebih besar dari lapangan. Namun, menghasilkan waste besi yang terkecil.

- Jika menggunakan tanda "=", maka menghasilkan kebutuhan besi yang terkecil. Namun, menghasilkan waste besi yang lebih besar dari hasil tanda " $>=$ " dan lebih kecil dari waste besi di lapangan.

Dalam penelitian ini digunakan fungsi kendala dengan tanda "=" untuk memperoleh kebutuhan besi minimum sehingga didapatkan penghematan besi tulangan antara metode linear programming dengan praktik di lapangan.

b. Terdapat dua cara pengerjaan dengan metode linear programminguntuk menghasilkan penghematan yaitu:

- Mengerjakan berdasarkan diameter pada pekerjaan masing-masing (misal: pekerjaan kolom, pekerjaan balok, dll.).

$>$ Proyek $\mathrm{X}=3,6 \%$

$>$ Proyek $\mathrm{Y}=3,9 \%$

- Mengerjakan berdasarkan diameter yang digabungkan

$>$ Proyek $X=4 \%$

$>$ Proyek $\mathrm{Y}=4,51 \%$

Berdasarkan hasil tersebut, dapat dilihat tidak terdapat peningkatan yang signifikan antara diameter yang digabungkan terhadap diameter pada pekerjaan masing-masing. Namun, pengerjaan linear programming dengan menggabungkan diameter besi tulangan membutuhkan waktu pengerjaan yang cukup lama karena banyaknya variasi panjang potongan dan membutuhkan area stok material yang lebih besar sehingga cara pertama yang lebih layak dilaksanakan di lapangan.

c. Metode Linear Programming tidak cocok atau kurang efektif digunakan jika variasi panjang potongan lebih dari 10 macam ukuran untuk setiap diameter tulangan. Hal ini dikarenakan semakin banyak variasi panjang potongan maka semakin lama waktu yang dibutuhkan untuk membuat variabel keputusan dan model Linear Programming, mengingat alternatif dan model dibuat dengan cara manual. Pekerjaan yang mudah untuk dianalisis adalah pekerjaan kolom dan shear wall/core wall. Namun, jika ada program yang dapat mengeluarkan 
alternatif pemotongan dan model Linear Programming maka metode ini sangat efektif untuk diterapkan di proyek kontruksi gedung bertingkat.

\section{Saran}

Untuk penelitian selanjutnya perlu dibuat sebuah program yang menghasilkan alternatifalternatif pemotongan besi tulangan sehingga tidak perlu berulang-ulang membuat alternatifalternatif dan menuliskan model Linear Programmingnya secara manual.

\section{REFERENSI}

Anonim. (2000). "Cement and Concrete Terminology (ACI 116R-00). American Concrete Institute.

Kork, M., Hartono, W. dan Sugiyarto. (2013). "Perhitungan Kebutuhan Tulangan Besi Dengan Memperhitungkan Optimasi Waste Besi Pada Pekerjaan Balok Dengan Program Microsoft Excel." e-Jurnal MATRIKS TEKNIK SIPIL Surakarta.

Kusuma, V. A. (2013). "Analisis dan Evaluasi Sisa Material Konstruksi." Edisi Revisi. Surakarta: Fakultas Teknik Universitas Sebelas Maret.

LINDO Systems, Inc. (2003). "LINDO User's Manual." LINDO. (http://www.LINDO.com/downloads/PDF/LINDOUsersManual.pdf) [27 Oktober 2016].

Mulyono, S.(2007). "Riset Operasi." Edisi Revisi. Jakarta: Fakultas Ekonomi Universitas Indonesia.

Siringoringo, H. (2008). “Seri Teknik Riset Operasional Pemrograman Linear.” Graha Ilmu, Jakarta.

Sutanto, Lenny Mayasari, dan Mita Dwi Purwanti. (2006). "Penyiapan Bar Bending Schedule untuk Proyek Konstruksi." Skripsi: Jurusan Teknik Sipi Fakultas Teknik Universitas Kristen Petra Surabaya.

The Constructor-Civil Engineering Home. (2015). "Preparation Of Bar Bending Schedule.” The Constructor.org. (http://theconstructor.org/practical-guide/preparation-of-bar-bendingschedule/7629/ [23 Oktober 2016].

Wahyu, P. A. (2014). "Rancangan Program Pengerjaan Bar Bending Schedule Penulanan Core Lift dan Pit Lift dengan Visual Basic 6.0." Skripsi: Program Studi Fakultas Teknik Universitas Kristen Petra Surabaya.

Winston, W. L. (2004). "Operations Research Application and Algorithms." Fourth Edition, Brooks/Cole, California. 